University of Michigan Law School

University of Michigan Law School Scholarship Repository

Articles

Faculty Scholarship

1922

\title{
Joint Tenancy in Personal Property in Michigan
}

Ralph W. Aigler

University of Michigan Law School

Available at: https://repository.law.umich.edu/articles/1235

Follow this and additional works at: https://repository.law.umich.edu/articles

Part of the Property Law and Real Estate Commons, and the State and Local Government Law Commons

\section{Recommended Citation}

Aigler, Ralph W. "Joint Tenancy in Personal Property in Michigan." Mich. L. Rev. 20 (1922): 219-21.

This Response or Comment is brought to you for free and open access by the Faculty Scholarship at University of Michigan Law School Scholarship Repository. It has been accepted for inclusion in Articles by an authorized administrator of University of Michigan Law School Scholarship Repository. For more information, please contact mlaw.repository@umich.edu. 
Joint Tenancy in Personal, Property in Michigan-In Lober v. Dorgan, 215 Mich. 62, decided July I9, I921, the court again wrestled with the problem which has troubled the Michigan courts for many years, as to whether the law of the state recognizes any such thing as joint ownership in personal property with the common law incident of survivorship. The facts presented a controversy between the estates of husband and wife, the latter having survived the former. A real estate mortgage had been given to "George W. Bush and Sarah Bush, his wife, of Gobleville, Michigan, as joint tenants, with sole right to the survivor." After the husband's death Mrs. Bush collected part of the sum due and the suit was for an accounting as to the sum so collected. It was held, Steere, C. J., and Fellows and Stone, JJ., dissenting, that Mrs. Bush by right of survivorship was entitled to the whole sum.

In arriving at this conclusion it was necessary for the majority either to repudiate Ludzerg v. Bruner, 203 Mich. 556 (I918), or to distinguish it. The latter course was taken, and the distinction in facts seized upon was the presence in the Lober case mortgage of the words "with the sole right to the survivor." In the principal case Bird, J., does not go so far as to say that a joint tenancy in personal property with the common law incident of survivorship may be created in Michigan; 'he merely holds that the parties to the mortgage 
may by contract provide for survivorship. Whatever may be thought of the basic question regarding joint tenancy in personal property with its common law incidents, it is believed that the learned court in its decision puts itself upon very dubious ground.

In the first place, the kinds of estates and tenancies which parties are allowed to create is not merely a matter of the parties' freedom of contract. The types of estates and tenancies which the law will recognize are few and in a sense arbitrary. For example, no court would give literal effect to a conveyance "to A and his male heirs," no matter how clearly the desire of the parties to the deed to have such estate may have been expressed. The common law recognized inheritable estates only as fees simple or fees tail. The example proposed is neither, and the construction of such limitation would be merely to eliminate the word "male." And it is of course common knowledge that within any particular class of estates there were distinct common law limitations upon the parties' freedom. The Rule against Perpetuities has interfered many times with the plans of grantors and devisors. For its conclusion regarding the freedom and potency of contract to provide for survivorship the court relies largely on Equitable Loan and Security Co. v. Waring, II7 Ga. 599 , in which the court was considering whether an investment certificate scheme involving certain features of lapse and survivorship was illegal as a lottery. Taylor v. Smith, Ix6 N. C. 53I, quoted from in the Georgia case, merely decided that co-owners of a note could make a valid contract that on the death of either without issue the note should belong to the survivor. And Arnold v. Jack's Ex'rs. 24 Pa. St. 57, also relied upon in the Georgia case, decided that it was possible to limit an estate in land to two or more for life as co-owners with cross remainders to the survivor.

The only possible support for the conclusions of the majority would seem to be in the possibility of treating the words "with sole right to the survivor" as creating an interest in the mortgage in the nature of a remainder. It is possible that Bird, $J$., had this in mind in speaking of freedom of contract. Whether the quoted words are sufficient to create a future interest in personal property is, it is submitted, extremely doubtful. It would be questionable whether they would be effective to create a remainder even in the case of real property.

In Wait $\nabla$. Bovee, 35 Mich. 425 , there was announced a decision which fairly warranted the statement thereafter frequently made by the court that "under our decisions the right of survivorship does not obtain in personal property held in joint ownership." Hart v. Hart, 20I Mich. 207, 213 (IgI8), in which Bird and Kuhn, JJ., dissented from the proposition quoted. The decision of the case, however, was neither an affirmance nor rejection of the view. Later in the same year in the Ludzuig case, supra, Ostrander, C. J., and Steere, Stone, and Kuhn, JJ., concurred with Mr. Justice Fellows in application of the doctrine of Wait v. Bovee. Bird, Moore, and Brook, JJ., dissented, claiming that the law would recognize joint tenancy with right of survivorship in personal property if provided for by the parties. In the principal case the new members of the court, Wiest, Clark, and Sharpe, JJ., joined Bird and Moore, JJ., in the view expressed by the former in his dis- 
senting opinion in the Ludwig case. Steere, C. J., and Stone, and Fellows, JJ., adhered to what had been their prevailing view in the earlier case, namely, that survivorship in joint ownership of personal property would not be recognized even though the parties make it clear that they intend such incident to attach.

The decision in the principal case purports, according to the prevailing opinion, to be entirely consistent with the earlier cases in the State. It is, however, a rejection of the view announced in the court's opinion in the Ludwig case that the quality of survivorship can not be attached by an expression of intention to that effect. In dealing with this question Michigan lawyers must address themselves to this inquiry: have the parties contracted for the incident of survivorship? According to the Lildwig case no such contract or intention is shown by a provision in the instrument of title that the co-owners are to hold "as joint tenants." But if there are added the words "with sole right to the survivor," then, according to the principal case, there is joint tenancy as at common law so far as survivorship is concerned.

There remains to be said only that at common law joint tenancy was applicable to personal as well as real property. Lirr. 28r; Co. Lirr., I8za; 2 KenT's Comrs.* 350. An early exception was made as to the incident of survivorship in the case of property used in trade or agriculture. 2 KENT's Comm., *350. And the same general policy against joint tenancies in realty has found some expression in the case of personalty. SCHOULER, PERs. PRop. $\$$ I56. The public policy of the State of Michigan regarding this matter is perhaps indicated in part at least by COMP. LAwS of I9I5, sec. 8040, wherein it is provided that deposits in bank in the name of the depositor or any other person, "and in form to be paid to either or the survivor" thereby become the property of such persons "as joint tenants," with right of survivorship. This statute which is a copy of a New York Act was held valid in In re Rehfeld's Est., I98 Mich. 249.

R. W. A. 